\title{
Growth Performance, Gonadal Weight and Fecundity: A Comparative Study of Rastrineobola argetea and Roasted Soybean Meal as Protein Ingredients for Brood Stock African Catfish (Clarias gariepinus) in Uganda
}

\author{
Robert Muyinda ${ }^{1}$, Henry Felix Emejje ${ }^{1}$, Gerald Zirintunda ${ }^{*}$, Keneth Iceland Kasozi ${ }^{1,2}$, \\ Abel Patrick Mawadri ${ }^{3}$ \\ ${ }^{1}$ Department of Animal Production and Management, Faculty of Agriculture and Animal Sciences, Busitema University, Soroti, \\ Uganda \\ ${ }^{2}$ Faculty of Biomedical Sciences, Kampala International University Western Campus, Bushenyi, Uganda \\ ${ }^{3}$ The National Animal Genetic Resource Centre and Databank, Entebbe, Uganda \\ Email: ^gziri@covab.mak.ac.ug
}

How to cite this paper: Muyinda, R., Emejje, H.F., Zirintunda, G., Kasozi, K.I. and Mawadri, A.P. (2021) Growth Performance, Gonadal Weight and Fecundity: A Comparative Study of Rastrineobola argetea and Roasted Soybean Meal as Protein Ingredients for Brood Stock African Catfish (Clarias gariepinus) in Uganda. Open Access Library Journal, 8: e6436.

https://doi.org/10.4236/oalib.1106436

Received: May 17, 2020

Accepted: January 26, 2021

Published: January 29, 2021

Copyright $\odot 2021$ by author(s) and Open Access Library Inc.

This work is licensed under the Creative Commons Attribution International License (CC BY 4.0).

http://creativecommons.org/licenses/by/4.0/ (c) (i) Open Access

\begin{abstract}
Rastrineobola argetea (fishmeal) was compared to roasted soybean meal as protein ingredients for brood stock African cat fish (Clarias gariepinus) in March 2019 on Geossy farm, Uganda. The fish were observed for growth and reproductive indices. Brood stocks of average weight $327 \mathrm{~g}$ were fed on different feeds for a month. Feed A contained soybeans as the sole main protein source. Feed B contained fishmeal as the sole protein source. Feed C was the control (usual farm feeds). Growth indices of B were significantly higher than of A $(p=0.0001, P<0.05)$. It is implausible to substitute fishmeal $100 \%$ by soybean meal even with heat treatment to remove ant nutritional factors. Fish meal has essential amino acids and fatty acids that are not in soybeans, soybeans can best be used in combination with fishmeal but the most economical ratios need more research. The reproductive indices had no significant differences for feed A, B and control. Replacing fish meal with soybeans had no significant effect on the reproductive indices. Fish meal increases the growth indices and the gonadal weight of Clarias gariepinus, soybean meal is good during brood stock management because it increases fecundity although lighter eggs are observed.
\end{abstract}

\section{Subject Areas}

Aquaculture, Fisheries \& Fish Science 


\section{Keywords}

Clarias gariepinus, Rastineobola argetea, Soybeans, Growth, Reproductive

\section{Introduction}

The African cat fish (Clarias gariepinus) farming in Uganda is getting popular in the scaling up of food security because they have better adaptability for apparently stressful conditions for other fish species (Abdel-Warith et al. 2019) [1]; Oni and Olaleye, 2013 [2]). Fish growth is dependent on factors like the type of feed and the water quality (Amisah et al. 2009 [3]; Otubusin et al. 2009) [4]. Exposure to darkness is said to improve the growth of Clarias gariepinus especially in conjunction with a good nutrient balance (Almazán-Rueda et al. 2004 [5]; Appelbaum \& Kamler, 2000 [6]). Growth of Clarias gariepinus is the best at low stocking densities (Hengsawat et al. 1997 [7]; Hossain et al. 1998 [8]). It is recommended that catfish brooders be fed a typical $28 \%$ - or $32 \%$-protein feed once daily at a rate of about $0.5 \%$ - $1 \%$ fish body weight (Robinson and Li 2001) [9].

Protein is one of the most essential nutrients for fish growth and maintenance of physiological functions (Amoah, 2011) [10]. Farmers prefer animal protein sources because of their superior amino acid composition and digestibility (Hecht, 2013 [11]; Masette \& Bamwirire, 2013 [12]; Ugwoke, 2013 [13]). Protein composition should range between $45 \%$ - 50\% in which the optimal being $46.1 \%$ for catfish (Hien et al. 2018) [14]. It must consist of various amino acids required for normal body functions (Hien et al. 2018) [14]. Protein ingredients should contain more than 20 percent crude protein, while energy ingredients usually have less than 20 percent crude protein and less than 18 percent crude fiber (Gatlin, 2010) [15]. The quality of proteins used determines the survival, growth, reproduction, feed efficiency and chemical composition of catfish (Mohanta et al. 2013 [16]; Ugwoke, 2013 [13]). In immature fish, a well-balanced diet with high protein levels is essential during the laying down of germinal tissue containing future egg stock and egg development during breeding (Khan et al. 2003 [17]; Mwanja et al. 2015 [18]). The female fish also require adequate proteins for egg development, formation of follicles and other ovarian tissues and in general reproduction (James and Sampath, 2003) [19]. However, the expanding demand for fish meal (Rastrineobola argetea) for aquaculture, poultry and livestock feed production (Huntington and Hasan, 2012) [20] has made it unacceptably too expensive (Mohanta et al. 2013) [16]. Fish meal contains DM (88\%), CP (60\%), CF (1\%), Ca (4.37\%), P (2.53\%), ME (2310 Kcal/kg), Lysine (4.08\%) and Methionine (1.70\%); soybean meal contains DM (88\%), CP (43\%), CF (6\%), Ca (0.53\%), P (0.64\%), ME (2800 Kcal/kg), Lysine (2.84\%) and Methionine (0.65\%); maize bran contains DM (88\%), CP (9.4\%), CF (13\%), Ca (0.04\%), P (1.03\%), ME (2200 Kcal/kg), Lysine (0.18\%) and Methionine (0.21\%); (UNBS, 2019) [21]. 


\section{Problem Statement}

The scarcity and cost of fish meal may lead to over $65 \%$ of the operating costs of aquaculture (Nwanna et al. 2014) [22]. This narrows the profit margin of fish farmers at the end of the culture period (Eyo et al. 2014) [23]. Overdependence on fishmeal makes commercial production of catfish capital intensive as it accounts for between $30 \%$ and $60 \%$ of variable operating costs (Amisah et al. 2009 [3]; Huynh \& Portfolio, 2010 [24]). However plant protein source like soybean meal contains (43 - 47)\% crude protein, (1.5 - 1.9)\% crude fat (UNBS, 2019) [21]. Soybeans are good protein sources but have anti-nutrients (protease and trypsin inhibitor activity, lectins, phytates, glucosinolates, saponins, and tanins) which are harmful to fish (Bueno et al. 2018) [25] despite the low cost and availability. Soybeans have low histidine, lysine, methionine and threonine amino acids (Zarate \& Lovell, 1997) [26]. There are many formulations of Clarias gariepinus feeds on the Uganda market (Hecht, 2013 [11]; Munguti, 2012 [27]) but studies haven't come up with reasonable economical formulas making farmers incur losses helplessly. There are many locally available materials that could be used to come up with efficient diets (Munguti, 2012) [27] but research to develop effective Clarias gariepinus feeds for the local market is still limited. There is need for innovations that enable successful use of plant ingredients like soybeans which are known to contain anti-nutrients. Heat treatment of the soybeans removes the anti-nutritional factors which are harmful (Anderson, 1992 [28]; Liener \& Tomlinson, 1981 [29]; Peres et al. 2003 [30]).

The purpose of this study was to compare the growth performance and the reproductive performance of Clarias gariepinus fed on roasted soybean protein source to those that were fed on fish meal (Rastrineobola argetea) protein source. The parameters of growth performance were weight gain, specific growth rate and protein efficiency ratios. The parameters of reproductive performance were gonadal weight, gonadal somatic index and fecundity.

\section{Materials and Methods}

\subsection{Study Area}

The study was carried out in Asinge village off the Tororo-Malaba highway at the Aquaculture Geossy fish farm $633222.19^{\circ} \mathrm{E} 71866.65^{\circ} \mathrm{N}$ UTM $36 \mathrm{~N}$ zone in Tororo district in the Eastern Uganda from April to May 2019.

\subsection{Sample Preparation and Treatment}

Mono sex female juvenile catfish used for the study were obtained from the National Fisheries Resources Research Institute Entebbe. A total of 30 fishes were acclimatized without food for 3 days prior to the commencement of the feeding trial at the farm. At the end of the 3 days of acclimation period, juvenile fish of mean weight $327 \mathrm{~g}$ were randomly distributed into groups of 10 in 3 circular cemented tanks of 4 cubic meter capacity. The experimental set up was supplied with water through a flow system and oxygen was augmented with a one horse- 
power aerator. Fecal wastes and feed remnants were removed daily by siphoning using a vacuum pump. Water changes were done during sampling days.

\subsection{Diet Formulation and Preparation}

The ingredients to be used were submitted to the college of Agriculture and Environmental Sciences, Makerere University for determination of crude protein content and it was found to be $43.2 \%$ for the soybean meal, $61.37 \%$ for Rastrineobola argetea (fish meal), $10.48 \%$ for the maize bran and $12.71 \%$ for the Geossy farm feeds (feed treatment $\mathbf{C}$ ) which was the control. Ingredients were weighed following calculations of Pearson square method using a CP of $46.1 \%$. The control feed was a farm formulated whose records stated that $100 \mathrm{~kg}$ contained $25 \mathrm{~kg}$ of wheat pollard, $35 \mathrm{~kg}$ of bread waste, $40 \mathrm{~kg}$ of Rastrineobola argetea and $100 \mathrm{~g}$ of mineral-vitamin premix.

Feed treatment (A) was composed $7.4 \mathrm{~kg}$ soybean (crude proteins-43.2\%), $0.6 \mathrm{~kg}$ maize bran (crude proteins-10.48\%) and $0.04 \mathrm{~kg}$ of mineral and vitamin premix to make an approximately $8 \mathrm{~kg}$ sample of $46.1 \%$ crude proteins. Feed treatment (B) was composed of $5.6 \mathrm{~kg}$ of Rastrineobola argetea (crude proteins-61.37\%), $2.4 \mathrm{~kg}$ of maize bran (crude proteins-10.48\%) and $0.04 \mathrm{~kg}$ of mineral and vitamin premix to make an approximately $8 \mathrm{~kg}$ sample of $46.1 \%$ crude proteins. They were uniformly mixed and warm water was added to make a dough. The material was pelleted manually using a meat-mincing machine and dried at $60^{\circ} \mathrm{C}$ for 48 hours in a hot air oven. The pellets were ground into bits and stored under room temperature in labelled airtight containers.

Fish were fed a mass $5 \%$ their body weight twice a day (Ahmed et al. 2019) [31] (daily (08:00-09:00 am, 05:00-6:00 pm) throughout the week including weekends for a 30 day growth period. The standard body weight of all the fish under each of the dietary treatment was weighed fortnightly using a digital balance $(0.1 \mathrm{~g})$ (Ali \& Jauncey, 2005) [32]. Fish were starved overnight prior to weighing. Adjustment of feed was done at the end of every weighing to feed $5 \%$ of the new body weight.

Weight Gain (WG), Specific Growth Rate (SGR), Protein Efficiency Ratio (PER), Protein Intake (PI), gonadal weight and fecundity were calculated using methods described below by Ahmed et al. (2019) [31];

Equation 1;

Weight gain $($ WG $)=$ Final body weight $(g)$ - Initial body weight $(g)$

\section{Equation 2;}

$$
\begin{aligned}
& \text { Specific growth rate(SGR) } \\
& =\frac{\operatorname{In}(\text { Final body weight })-\operatorname{In} \text { (Initial body weight })}{\text { Time }(\text { days })} \times 100
\end{aligned}
$$

\section{Equation 3;}

Protein efficiency ratio $($ PER $)=\frac{\text { Final body weight }- \text { Initial body weight }}{\text { Amount of protein fed }}$ 


\section{Equation 4;}

$$
\text { Gonadosomatic index }(\text { GSI })=\frac{\text { Weight of ovary }}{\text { Weight of fish }} \times 100
$$

\section{Equation 5}

$$
\text { Fecundity }=\frac{\text { Number of eggs in sub sample } \times \text { Gonad weight }}{\text { Weight of sub sample }}
$$

\subsection{Selection of Brood-Stock}

The fish used was captured using a net from the pond. After selection, breeders were then put in separate concrete tanks filled with .well oxygenated and clean water. Only females were selected and the selection was done in the evening quickly and carefully to avoid oxygen deprivation and minimize injuries.

\subsection{Brood-Stock Management}

Brood stock management involved caring for the brood stock from the time the fish was captured and brought for breeding to the time of, stripping and return to the pond. Cleaning of the tanks, changing of the water and feeding the fish three times a day on $5 \%$ of their body weights for feed treatments $\mathrm{A}, \mathrm{B}$ and $\mathrm{C}$. Feeding was started 12 hours after the experimental setup to allow the fish rest. Feeding was done for four weeks.

\subsection{Hormone Processing and Administration}

Just prior to hormone administration on the $28^{\text {th }}$ day of the experiment, the pituitary gland was extracted from seven donor catfish (Andrus et al. 1992) [33]. The extracted pituitary gland was then placed in a micro vial and sterile double stilled water added. After grinding it using micro-pestle and more distilled water was added in order to achieve concentration of $40 \mathrm{mg} / \mathrm{ml}$ of pituitary extract and mixed thoroughly. This was then followed by centrifuging the extract for about 1 minute to separate the tissue debris from the extract. A required amount of clear supernatant was then withdrawn into a syringe and the recipient fish injected via the intramuscular route in the anterior caudal region (Haniffa \& Sridhar, 2002) [34]; the fish were injected depending on weight at a dosage rate of $0.5 \mathrm{ml} / \mathrm{kg}$ body weight (Abubakar and Ipinjolu, 2019) [35]. Each was weighed before hormone administration to obtain the final weight after treatment to help calculate the weight gain. After hormone administration, each fish was put in a separate well labelled plastic can tank containing water where they stayed overnight for the latency period.

\subsection{Harvesting of Ripe Eggs by Stripping}

After the latency period Procedures of FAO (1994) were done with minor modifications, the fish was ready for stripping as the following signs indicated readiness for stripping; a well-rounded and soft abdomen, eggs also showed clear nucleus at the center and the genital opening was swollen and for some reddish 
in colour. Each fish; one at a time was then placed in a bucket, disinfected and cleaned using a towel before transferring to the stripping bowl. The fish was held at the base of the tail with the left hand by one person and the head placed using the left hand by another person with the fish belly facing down. The fish head was then slightly elevated so that the eggs flow towards the vent by gravity. The fish was then caught with the right hand and the thumb put on one side of the belly and fingers on the other side just ahead of the pelvic fins. It was then gently squeezed as the hand was being slide back towards the vent. The milking process continued until the eggs stopped flowing and the eggs were weighed.

\subsection{Determining the Fecundity}

After stripping the eggs, the eggs from each fish was weighed to get the weight of the entire egg mass from one fish, a one (1) gram sample from each egg mass was then measured separately in plastic plates (Dadebo et al. 2011) [36]. The eggs from each sample were then mixed with potassium permanganate to separate the eggs from one another in order to facilitate easy counting which was done physically. The number of eggs stripped from each fish was then calculated by multiplying the weight of the egg mass (from each female) by the number of eggs present in sampled one gram of the respective egg masses from the different fishes.

\subsection{Data Analysis}

Primary data was determined from the fish, other variables were determined from the Equations (1-6) above and entered into a table (Table 1). Tukey's multiple comparison test on weight changes, growth rates, PER, gonadal weight and fecundity in fish exposed to the three feeds was done. Graph pad prism was used to make graphs to confirm the comparisons.

\section{Results and Discussion}

Data from MS-excel was used to generate data in Table 1.

\subsection{Feed Effects on Growth Performance}

The mean weight gain, specific growth rate and protein efficiency ratios were greater in group B\&C and lowest in group A (Figure 1, graph 1-3). There was a significant difference in weight gains in fish on feed treatment $\mathbf{B}$ and $\mathbf{A}$ (Table 2) possibly because of the amino acid profile of feed $\mathbf{B}$. There was a significant difference in weight gains in fish on feed treatment $\mathbf{C}$ (control) and $\mathbf{A}$ (Table 2) possibly because of the ingredients in wheat pollard and bread waste in C. Mean weight gain in group $\mathbf{B}$ was higher than in A (Figure 1, graph 1) because the diet with the highest protein leads to higher body weight gain (Degani et al. 1989) [37]. Higher weight gain in treatment B than in A could have been due to the better balance of amino acid profile and digestibility of the protein ingredient in Rastrineobola argetea and anti-nutritional remnants in soybean. This observation is in agreement with (Abdel-Warith et al. 2019 [1]; Amisah et al. 2009) [3] 
who reported that every time fishmeal was left out in diet formulation, it led to low weight gain. Soybean meal contains low levels of essential amino acids (methionine and lysine) resulting in poor growth and feed utilization in fish. (Yang et al. 2009) [38]. The findings agree with Goda et al. (2007) [39] about the possibility of better growth with partial replacement of fishmeal with soybean. However, the findings of the study disagree with Adewumi, (2006) [40] who proposed that heat treatment of a certain level could make soybean an absolute replacement of fish meal. Equivocally the findings disagree with Ajani et al. (2016) [41] who partially inferred that soybean can replace fish meal by $100 \%$ as protein sources and make Clarias gariepinus attain acceptable growth performance. This indicates that Soybeans can best be used in combination with Rastrineobola argetea (Goda et al. 2007) [39] and not as a sole protein source regardless of the methods of removing the anti-nutritional factors. Phytase treatment will only improve the digestibility of phosphorus (Weerd et al. 1999) [42] and this will also not make soybeans absolute fish meal replacers. Group C (control feeds) had the highest mean weight gain because it contained wheat pollard and bread waste and not maize bran as the experimental feeds. Bread waste is known to produce better growth performance compared to maize (Fakunmoju, 2014) [43].

Table 1. Growth and Reproductive indices of Clarias gariepinus on different feed treatments from Geossy fish farm, Tororo in March 2019.

\begin{tabular}{|c|c|c|c|c|c|c|c|c|c|c|c|}
\hline Sample & $\begin{array}{l}\text { Initial } \\
\text { weight } \\
(\mathrm{g})\end{array}$ & $\begin{array}{c}\text { Final } \\
\text { weight } \\
(\mathrm{g})\end{array}$ & $\begin{array}{c}\text { Gonadal } \\
\text { weight } \\
\text { (g) }\end{array}$ & $\begin{array}{c}\text { No of } \\
\text { eggs in } 1 \\
\text { g sample }\end{array}$ & $\begin{array}{l}\text { weight } \\
\text { gain (g) }\end{array}$ & $\begin{array}{l}\text { In (weight } \\
\text { gain) }\end{array}$ & $\begin{array}{l}\text { Specific } \\
\text { growth } \\
\text { rate }\end{array}$ & $\begin{array}{l}\text { Protein } \\
\text { efficiency } \\
\text { ratio }\end{array}$ & $\begin{array}{l}\text { Gonadal } \\
\text { somatic } \\
\text { index }\end{array}$ & $\begin{array}{l}\text { Fecundity } \\
\text { (Eggs) }\end{array}$ & $\begin{array}{c}\text { Fecundity } \\
\text { in } 1000\end{array}$ \\
\hline A & 447 & 456 & 18 & 30,000 & 9 & 2.20 & 7.86 & 0.193 & 3.947 & 540,000 & 540 \\
\hline A & 371 & 378 & 14 & 29,120 & 7 & 1.95 & 6.96 & 0.150 & 3.704 & 407,680 & 407.68 \\
\hline A & 364 & 372 & 15 & 31,200 & 8 & 2.08 & 7.43 & 0.172 & 4.032 & 468,000 & 468 \\
\hline A & 326 & 342 & 31 & 64,480 & 16 & 2.77 & 9.89 & 0.343 & 9.064 & $1,998,880$ & 1998.88 \\
\hline A & 291 & 310 & 6 & 12,480 & 19 & 2.94 & 10.50 & 0.408 & 1.935 & 74,880 & 74.88 \\
\hline A & 287 & 291 & 32 & 66,560 & 4 & 1.39 & 4.96 & 0.086 & 10.997 & $2,129,920$ & 2129.92 \\
\hline A & 285 & 288 & 22 & 45,760 & 3 & 1.10 & 3.93 & 0.064 & 7.639 & $1,006,720$ & 1006.72 \\
\hline B & 400 & 440 & 19 & 35,000 & 40 & 3.69 & 13.18 & 0.858 & 4.318 & 665,000 & 665 \\
\hline B & 345 & 392 & 24 & 18,024 & 47 & 3.85 & 13.75 & 1.009 & 6.122 & 432,576 & 432.576 \\
\hline B & 317 & 372 & 29 & 21,779 & 55 & 4.01 & 14.32 & 1.180 & 7.796 & 631,591 & 631.591 \\
\hline B & 304 & 364 & 36 & 27,036 & 60 & 4.09 & 14.61 & 1.288 & 9.890 & 973,296 & 973.296 \\
\hline B & 304 & 338 & 39 & 29,289 & 34 & 3.53 & 12.61 & 0.730 & 11.538 & $1,142,271$ & 1142.27 \\
\hline B & 270 & 320 & 6 & 4506 & 50 & 3.91 & 13.96 & 1.073 & 1.875 & 27,036 & 27.036 \\
\hline B & 261 & 298 & 34 & 25,534 & 37 & 3.61 & 12.89 & 0.794 & 11.409 & 868,156 & 868.156 \\
\hline $\mathrm{C}$ & 365 & 398 & 54 & 46,008 & 33 & 3.50 & 12.50 & 0.708 & 13.568 & $2,484,432$ & 2484.43 \\
\hline $\mathrm{C}$ & 366 & 391 & 40 & 34,080 & 25 & 3.22 & 11.50 & 0.536 & 10.230 & $1,363,200$ & 1363.2 \\
\hline $\mathrm{C}$ & 328 & 382 & 35 & 29,820 & 54 & 3.99 & 14.25 & 1.159 & 9.162 & $1,043,700$ & 1043.7 \\
\hline C & 325 & 377 & 33 & 28,116 & 52 & 3.95 & 14.11 & 1.116 & 8.753 & 927,828 & 927.828 \\
\hline $\mathrm{C}$ & 308 & 372 & 23 & 19,596 & 64 & 4.16 & 14.86 & 1.373 & 6.183 & 450,708 & 450.708 \\
\hline $\mathrm{C}$ & 301 & 351 & 24 & 20,448 & 50 & 3.91 & 13.96 & 1.073 & 6.838 & 490,752 & 490.752 \\
\hline $\mathrm{C}$ & 299 & 338 & 40 & 34,080 & 39 & 3.66 & 13.07 & 0.837 & 11.834 & $1,363,200$ & 1363.2 \\
\hline
\end{tabular}


Table 2. Tukey's multiple comparisons test on weight changes, growth rate, protein efficiency, gonadal weight and fecundity in fish exposed to 3 feed types from Geossy farm in Asinge, Tororo in March 2019 (Tukey test; $p<0.05, \mathrm{df}=6$ ).

\begin{tabular}{cccc}
\hline Tukey's multiple comparisons test & Feed A vs. Feed B & Feed A vs. Feed C & Feed B vs. Feed C \\
\hline Weight change & $<0.0001$ & $<0.0001$ & 0.9864 \\
Specific growth rate & $<0.0001$ & $<0.0001$ & 0.9824 \\
Protein efficiency ratio & $<0.0001$ & $<0.0001$ & 0.9862 \\
Gonadal weight & 0.4443 & 0.0294 & 0.2826 \\
Eggs per gram & 0.0841 & 0.4129 & 0.5965 \\
Gonadal somatic index & 0.6113 & 0.1219 & 0.5128 \\
Fecundity & 0.7233 & 0.8141 & 0.3675 \\
\hline
\end{tabular}

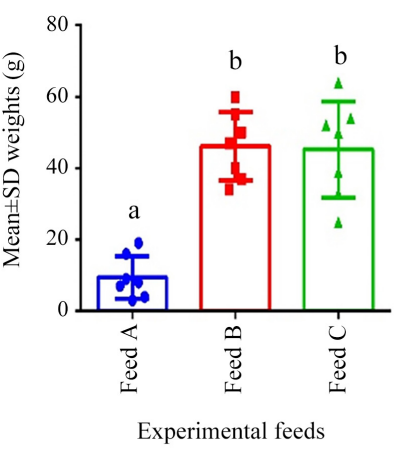

1

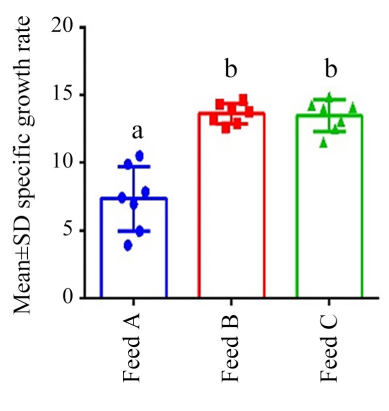

Experimental feeds

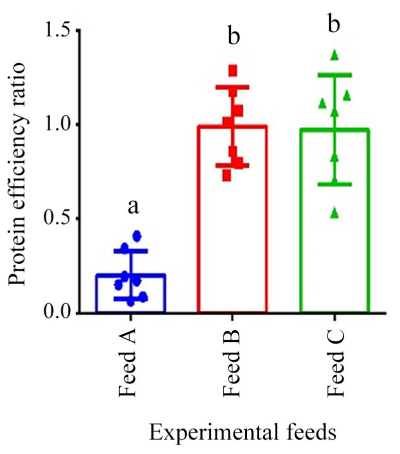

3

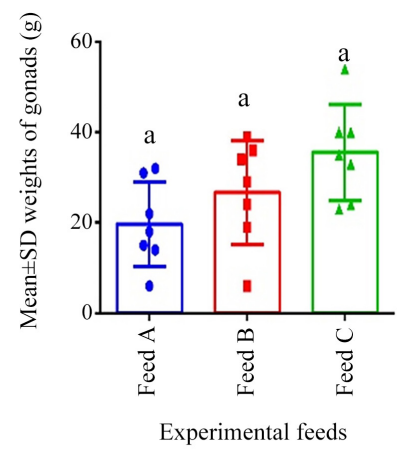

4

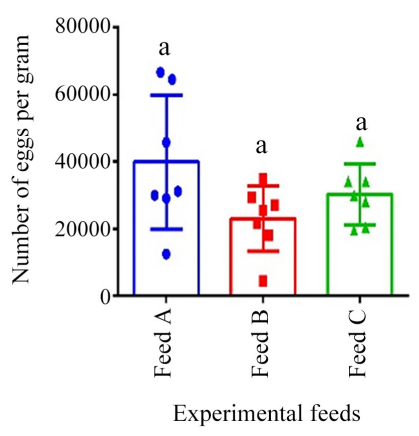

5

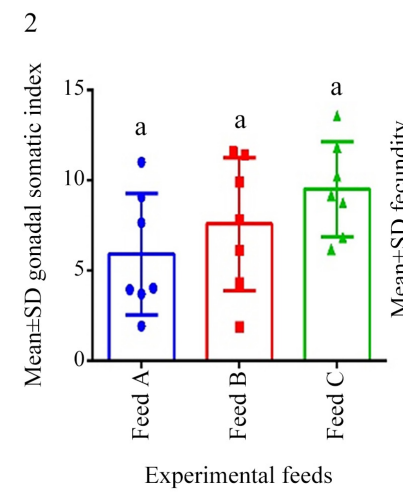

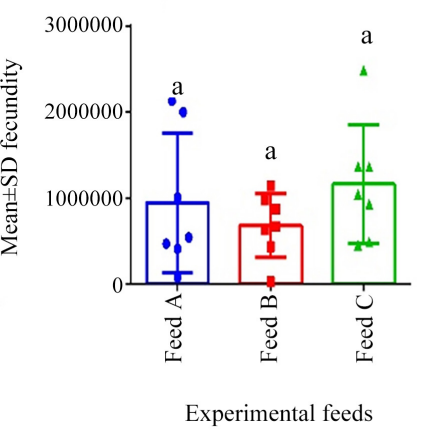

7

Figure 1. Shows the Feed effects on growth and reproductive performance indices. Graph (1) shows that feed B caused a significantly higher mean weight than feed A and feed B didn't cause a significantly higher mean weight than the control (feed C). Feed B and Feed C are all represented by "b" over the bars implying that they had similar effects on mean weight gain but Feed A is represented by letter "a" meaning that it is different from Feed B and C. Graph (2) shows that feed B caused a significantly higher specific growth rate than feed A and feed B didn't cause a significantly higher specific growth rate than the control (feed C). Feed B and C are all represented by "b" over the bars implying that they had no significant differences in effects on growth rate but Feed A is represented by "a" meaning that it had a different effect from that of Feed B and C. Graph (3) shows that feed B caused a significantly higher PER than feed A and feed B didn't cause significantly higher PER than the control (feed C). Feed B and C denoted by "b" over the bars caused a significantly higher PER than that of Feed A denoted by "a" over the bars. Graph (4) shows that there wasn't any significant differences in gonadal weights for feed A, B and the control (C); all denoted by "a" over the bars. Graph (5) shows that there wasn't any significant differences in number of eggs due to the feeds although the soybean protein source (feed A) caused more eggs; all denoted by “a” over the bars. Graph (6) shows that there wasn't any significant differences in the GSI due to the feeds A, B, C; all denoted by “a” over the bars. Graph (7) shows that there wasn't any significant differences in fecundity due to the feeds A, B, C; all denoted by "a" over the bars. 


\subsection{Feed Effects on Reproductive Performance}

Gonadal weight was highest in Feed C (Figure 1, graph 4), and number of eggs per gram were highest in Feed A (Figure 1, graph 5) while gonadal somatic index and fecundity were the highest in Feed C (Figure 1, graph 6-7), however, no significant differences were found for all the reproductive indices between Feeds A, B and C (Figure 1, graph 4-6). Tukey's multiple comparison test found a significant difference in effects on gonadal weights caused by the control feed $\mathrm{C}$ and feed A $(\mathrm{P}=0.0294, P<0.05)$ but the results of the graph pad prism graphs were used (Table 2 ). However, there was only a very small difference between the mean gonadal weight in treatment $\mathbf{C}$ and that of treatment $\mathbf{B}$. This is because increasing protein levels of the diet increase eggs size which is in agreement with (Quintero \& Davis, 2016) [44]. The findings are in agreement with (Çek \& Yilmaz, 2009) [45] who found that gonadal weight was increasing with the increasing energy in the feed. The studies in other geographical zones have stated that gonadal development is seasonal (Nyina-wamwiza et al. 2012 [46]; Romanova et al. 2018 [47]) but such studies haven't been done for Uganda; the seasonal effects on the reproductive indices are not known. The observed trend of gonadal weight is possibly the trend of $\mathrm{n}-3$ fatty acids in fish as compared to soybean meal (Kubiriza et al. 2020 [48]; Mwanja et al. 2015 [18]). Egg size is associated with higher total number of $n-3$ fatty acids as these fatty acids play an important structural role as components of phospholipids in fish bio-membranes (Izquierdo, 2001) [49].

There was no significant difference in the reproductive indices for the feed treatments; replacing fish meal with soybean didn't affect mean gonadal weight, number of eggs, GSI and fecundity. The findings are in agreement with Nyina-wamwiza et al. (2012) [46] who found out that replacing fish meal didn't affect the GSI. The findings don't agree with (Effiong et al. 2014) [50] who found that GSI increases with increased proteins in the diet. However, the study agrees with Ahmad (2008) who found that GSI may be increased by the right balance between crude proteins and lipids as was the control feed. The low average fecundity in treatment B (677,132 eggs) is most likely to be associated with high levels of n-3 highly unsaturated fatty acids (HUFA), which was present in the fishmeal which was used as a protein source. Lipid and fatty acid composition of broodstock diet have been identified as major dietary factors that determine successful reproduction (Barua, 2011) [51]. The findings are in agreement with (Izquierdo, 2001) [49] who reported that high levels of dietary n-3 HUFA which is in fish reduce the total amount of eggs produced. Soybeans contain n-6 HUFA which increases the average fecundity as was observed in feed $\mathbf{A}(5,763,177$ eggs) compared to treatment B $(677,132$ eggs) and the control C $(1,160,546)$; the finding is in agreement with (Izquierdo, 2001) [47]. The findings are not in agreement with Ekanem et al. (2013) [52]; Eyo et al. (1992) [53] whose findings associated fecundity directly with weight gain and gonadal weight of fish. This was possible because feeds were a major variable in this study. 


\section{Conclusion and Recommendations}

Feeding broodstock on fishmeal as a protein source increases in body weight and gonadal weight of Clarias gariepinus while soybean meal as a protein source increases fecundity. It's imperative to use soybeans during broodstock management but if it's to be used earlier then should be supplemented with lysine and methionine amino acids. However, research should be done on the hatchability and survivability of the fries from Clarias gariepinus brood that use soybean meal protein source because of the low egg weights that were observed. Replacing fish meal with soybean is a good economic strategy but the appropriate ratios for the various stages of Clarias gariepinus need further research.

\section{Acknowledgements}

The management of Geossy fish farm for allowing us to use your facilities to run our experiments.

\section{Conflicts of Interest}

The authors declare no conflicts of interest regarding the publication of this paper.

\section{References}

[1] Abdel-Warith, A.A., Younis, E.M., Al-Asgah, N.A. and Mahboob, S. (2019) Effect of Replacing Fish Meal by Full Fat Soybean Meal on Growth Performance, Feed Utilization and Gastrointestinal Enzymes in Diets for African Catfish Clarias gariepinus. Brazilian Journal of Biology, 80, 535-543. https://doi.org/10.1590/1519-6984.214763

[2] Oni, T.A. and Olaleye, V.O. (2013) Preliminary Studies on Associated Bacteria and Fungal Load of Artificially Cultured. Ife Journal of Science, 15, 9-16.

[3] Amisah, S., Oteng, M. and Ofori, J. (2009) Growth Performance of the African Catfish, Clarias gariepinus, Fed Varying Inclusion Levels of Leucaena leucocephala Leaf Meal. Journal of Applied Sciences and Environmental Management, 13, 21-26. http://www.bioline.org.br/ja https://doi.org/10.4314/jasem.v13i1.55257

[4] Otubusin, S.O., Ogunleye, F.O. and Agbebi, O.T. (2009) Feeding Trials Using Local Protein Sources to Replace Fishmeal in Pelleted Feeds in Catfish (Clarias gariepinus Burchell 1822) Culture. European Journal of Scientific Research, 31, 142-147.

[5] Almazán-Rueda, P., Schrama, J.W. and Verreth, J.A.J. (2004) Behavioural Responses under Different Feeding Methods and Light Regimes of the African Catfish (Clarias gariepinus) Juveniles. Aquaculture, 231, 347-359. https://doi.org/10.1016/j.aquaculture.2003.11.016

[6] Appelbaum, S. and Kamler, E. (2000) Survival, Growth, Metabolism and Behaviour of Clarias gariepinus (Burchell 1822) Early Stages under Different Light Conditions. Aquacultural Engineering, 22, 269-287. https://doi.org/10.1016/S0144-8609(00)00054-6

[7] Hengsawat, K., Ward, F.J. and Jaruratjamorn, P. (1997) The Effect of Stocking Density on Yield, Growth and Mortality of African Catfish (Clarias gariepinus Burchell 1822) Cultured in Cages. Aquaculture, 152, 67-76. https://doi.org/10.1016/S0044-8486(97)00008-2 
[8] Hossain, M.A.R., Beveridge, M.C.M. and Haylor, G.S. (1998) The Effects of Density, Light and Shelter on the Growth and Survival of African Catfish (Clarias gariepinus Burchell, 1822) Fingerlings. Aquaculture, 160, 251-258.

https://doi.org/10.1016/S0044-8486(97)00250-0

[9] Robinson, E.H. and Li, M. (2001) A Practical Guide to Nutrition, Feeds, and Feeding of Catfish. Mississippi.

[10] Amoah, Y.T. (2011) Effect of Dietary Protein Levels on Growth and Protein Utilization in Juvenile Arctic Char (Salvelinus alpinus).

[11] Hecht, T. (2013) A Review of On-Farm Feed Management Practices for North African Catfish (Clarias gariepinus) in Sub-Saharan Africa. FAO Fisheries and Aquaculture Technical Paper, 15-24.

http://search.ebscohost.com/login.aspx?direct=true\&db=lbh\&AN=20143141781\&lo gin.asp?custid $=$ magn $1307 \&$ site $=$ ehost-live\&custid $=$ magn 1307

[12] Masette, M. and Bamwirire, D. (2013) The Effect of Bleeding on the Quality of Farmed African Catfish in Uganda. Ugandan Journal of Agricultural Sciences, 14, 37-44.

[13] Ugwoke (2013) Effects of Supplementation of Fish Meal with Soybean Meal on the Growth and Gonad Development of the African Catfish (Clarias gariapinus). University of Nigeria, Nsukka.

[14] Hien, T.T.T., et al. (2018) Dietary Protein Requirement of Bighead Catfish. International Journal of Scientific and Research Publications, 8, 200-205.

https://doi.org/10.29322/IJSRP.8.11.2018.p8326

[15] Gatlin, D.M. (2010) Principles of Fish Nutrition. Aquacultural, 92, 1-8.

[16] Mohanta, K.N., Subramanian, S. and Korikanthimath, V.S. (2013) Evaluation of Different Animal Protein Sources in Formulating the Diets for Blue Gourami, Trichogaster Trichopterus Fingerlings. Journal of Aquaculture Research and Development, 4, Article ID: 1000164. https://doi.org/10.4172/2155-9546.1000164

[17] Khan, M.A., Jafri, A.K., Chadha, N.K. and Usmani, N. (2003) Growth and Body Composition of Rohu (Labeo rohita) Fed Diets Containing Oilseed Meals: Partial or Total Replacement of Fish Meal with Soybean Meal. Aquaculture Nutrition, 9, 391-396. https://doi.org/10.1046/j.1365-2095.2003.00268.x

[18] Mwanja, M.T., Ondhoro, C.C. and Aruho, C. (2016) Guidelines for African Catfish and Nile tilapia Seed Production \& Hatchery Management in. International Journal of Fisheries and Aquatic Studies, 4, 594-598. http://www.fisheriesjournal.com

[19] James, R. and Sampath, K. (2003) Effect of Animal and Plant Protein Diets on Growth and Fecundity in Ornamental Fish, Betta splendens (Regan). Israeli Journal of Aquaculture-Bamigdeh, 55, 39-52. http://hdl.handle.net/10524/19067

[20] Huntington, T. and Hasan, M.R. (2012) Fish as Feed Inputs for Aquaculture-Practices, Sustainability and Implications: A Global Synthesis. FAO Fisheries and Aquaculture Technical Paper No. 518, FAO, Rome, 1-61.

[21] UNBS Uganda National Bureau of Standards (2019) Uganda Standards Catalogue as at 31 March 2019. Uganda National Bureau of Standards, Kampala, 256.

[22] Nwanna, L.C., Omojala, I., Nwanna, E. and Abiodun, E. (2014) Effect of Protein Deficient Diets on the Growth and Carcass Protein Ash Ratio of African Catfish Clarias gariepinus (Burchell 1822). Journal of Applied Sciences and Environmental Management, 18, 537-541.

[23] Eyo, V.O., Ekanem, A.P. and Jimmy, U.U. (2014) A Comparative Study of the Gonado-Somatic Index (GSI) and Gonad Gross Morphology of African Catfish (Clarias gariepinus) Fed Unical Aqua Feed and Coppens Commercial Feed Study Area 
Formulation, Composition and Preparation of Unical Aqua Feed. Croatian Journal of Fisheries, 72, 63-69. https://doi.org/10.14798/72.2.706

[24] Huynh, H.P.V. and Portfolio, T. (2010) Evaluating the Use of Alternative Proteins in Feed on Growth and Nutrient Utilization of Australian Catfish, Tandanus tandanus with Emphasis on Environmental Contamination. School of Applied Sciences Science, Engineering and Technology Portfolio, Applied Sciences, RMIT University, Melbourne.

[25] Bueno, R.D., Borges, L.L., Good God, P.I.V., Piovesan, N.D., Teixeira, A.I., Cruz, C.D. and De Barros, E.G. (2018) Quantification of Anti-Nutritional Factors and Their Correlations with Protein and Oil in Soybeans. Anais Da Academia Brasileira de Ciencias, 90, 205-217. https://doi.org/10.1590/0001-3765201820140465

[26] Zarate, D.D. and Lovell, R.T. (1997) Free Lysine (L-Lysine HCl) Is Utilized for Growth Less Efficiently than Protein-Bound Lysine (Soybean Meal) in Practical Diets by Young Channel Catfish (Ictalurus punctatus). Aquaculture, 159, 87-100. https://doi.org/10.1016/S0044-8486(97)00184-1

[27] Munguti, J. (2012) Nutritive Value and Availability of Commonly Used Feed Ingredients for Farmed Nile tilapia (Oreochromis niloticus L.) and African Catfish (Clarias gariepinus, Burchell) in Kenya, Rwanda and Tanzania. African Journal of Food, Agriculture, Nutrition and Development, 12, 6135-6155.

[28] Anderson, R.L. (1992) Effects of Steaming on Soybean Proteins and Trypsin Inhibitors. Journal of the American Oil Chemists Society, 69, 1170-1176. https://doi.org/10.1007/BF02637675

[29] Liener, I.E. and Tomlinson, S. (1981) Heat Inactivation of Protease Inhibitors in a Soybean Line Lacking the Kunitz Trypsin Inhibitor. Journal of Food Science, 46, 1354-1356. https://doi.org/10.1111/j.1365-2621.1981.tb04173.x

[30] Peres, H., Lim, C. and Klesius, P.H. (2003) Nutritional Value of Heat-Treated Soybean Meal for Channel Catfish (Ictalurus punctatus). Aquaculture, 225, 67-82. https://doi.org/10.1016/S0044-8486(03)00289-8

[31] Ahmed, M., Liang, H., Chisomo, H., Ke, K., Xianping, J., Liu, B., Sun, A., et al. (2019) Complete Replacement of Fish Meal by Plant Protein Ingredients with Dietary Essential Amino Acids Supplementation for Juvenile Blunt Snout Bream ( $\mathrm{Me}$ galobrama amblycephala). Aquaculture Nutrition, 25, 205-214. https://doi.org/10.1111/anu.12844

[32] Ali, M.Z. and Jauncey, K. (2005) Approaches to Optimizing Dietary Protein to Energy Ratio for African Catfish Clarias gariepinus (Burchell, 1822). Aquaculture Nutrition, 11, 95-101. https://doi.org/10.1111/j.1365-2095.2004.00325.x

[33] Andrus, P., Shibabrata, N. and Samarendra, N.C. (1992) Manual on Seed Production of African Catfish (Clarias gariepinus).

http://www.fao.org/3/AC378E/AC378E00.htm

[34] Haniffa, M.A.K. and Sridhar, S. (2002) Induced Spawning of Spotted Murrel (Channa punctatus) and Catfish (Heteropneustes fossilis) Using Human Chorionic Gonadotropin and Synthetic Hormone (Ovaprim). Veterinarski Arhiv, 72, 51-56.

[35] Abubakar, M.Y. and Ipinjolu, J. (2019) Spawning Performance of Heterobranchus bidorsalis in Sokoto Dry Sub Humid Nigeria Using Ovaprim C and Ovatide Hormones. Asian Journal of Emerging Research, 1, 141-153.

[36] Dadebo, E., Gebre-Mariam, Z. and Mengistou, S. (2011) Breeding Season, Maturation, Fecundity and Condition Factor of the African Catfish Clarias gariepinus Burchell 1822 (Pisces: Clariidae) in Lake Chamo, Ethiopia. Journal of Biological Sciences, 10, 1-17. https://doi.org/10.4314/sinet.v32i1.67765 
[37] Degani, G., Ben-Zvi, Y. and Levanon, D. (1989) The Effect of Different Protein Levels and Temperatures on Feed Utilization, Growth and Body Composition of Clarias gariepinus (Burchell 1822). Aquaculture, 76, 293-301. https://doi.org/10.1016/0044-8486(89)90082-3

[38] Yang, S., Lin, T., Liu, F. and Liou, C. (2009) Dietary Effects of Fermented Soybean Meal on Growth Performance, Body Composition and Hematological Characteristics of Silver Perch (Bidyanus bidyanus). Journal of Taiwan Fisheries Research, 17, 53-63.

[39] Goda, A.M., El-Haroun, E.R. and Kabir Chowdhury, M.A. (2007) Effect of Totally or Partially Replacing Fish Meal by Alternative Protein Sources on Growth of African Catfish Clarias gariepinus (Burchell, 1822) Reared in Concrete Tanks. Aquaculture Research, 38, 279-287. https://doi.org/10.1111/j.1365-2109.2007.01663.x

[40] Adewumi, A.A. (2006) The Growth and Gonadal Maturation of the African Catfish, Clarias gariepinus (Burchell) Broodstock Fed Differently Heated Soybean-Based Diets. Aquaculture Nutrition, 12, 267-274. https://doi.org/10.1111/j.1365-2095.2006.00404.x

[41] Ajani, E.K., Orisasona, O., Omitoyin, B.O. and Osho, E.F. (2016) Total Replacement of Fishmeal by Soybean Meal with or without Methionine Fortification in the Diets of Nile tilapia, Oreochromis niloticus. Journal of Fisheries and Aquatic Science, 11, 238-243. https://doi.org/10.3923/jfas.2016.238.243

[42] Weerd, J.H., et al. (1999) Balance Trials with African Catfish Clarias gariepinus Fed Phytase-Treated Soybean Meal-Based Diets. Aquaculture Nutrition, 5, 135-142. https://doi.org/10.1046/j.1365-2095.1999.00100.x

[43] Fakunmoju, F. (2014) Breadwaste as a Dietary Supplement for Maize in the Practical Diets of African Giant Catfish (Clarias gariepinus, Burchell 1822) Fingerlings. IOSR Journal of Agriculture and Veterinary Science, 7, 89-92. https://doi.org/10.9790/2380-07158992

[44] Quintero, H.E. and Davis, D.A. (2016) Broodstock Nutrition: Enhancement of Egg Quality in Channel Catfish. Portal de Revistas UANL (January 2015).

[45] Çek, Ş. and Yilmaz, E. (2009) The Effect of Varying Dietary Energy on Gonad Development at First Sexual Maturity of the Sharptooth Catfish (Clarias gariepinus Burchell, 1822). Aquaculture International, 17, 553-563.

https://doi.org/10.1007/s10499-008-9224-4

[46] Nyina-wamwiza, L., Milla, S., Pierrard, M.A., Rurangwa, E., Mandiki, S.N.M., Van Look, K.J.W. and Kestemont, P. (2012) Partial and Total Fish Meal Replacement by Agricultural Products in the Diets Improve Sperm Quality in African Catfish (Clarias gariepinus). Theriogenology, 77, 184-194.

https://doi.org/10.1016/j.theriogenology.2011.07.032

[47] Romanova, E.M., Lyubomirova, V.N., Romanov, V.V., Mukhitova, M.E. and Shlenkina, T.M. (2018) Seasonal Studies of Caviar Production and the Growth Rate of the African Catfish (Clarias gariepinus, Burchell, 1822). Egyptian Journal of Aquatic Research, 44, 315-319. https://doi.org/10.1016/j.ejar.2018.09.005

[48] Kubiriza, G.K., Ssempijja, D., Mubiru, E., Semwanga, N., Odoli, C.O., Zalwango, J. and Masette, M. (2020) Oxidative Stability and Proximate Composition of Silver Cyprinid (Rastrineobola argentea) Used for Fishmeal in East Africa. Journal of Applied Aquaculture. https://doi.org/10.1080/10454438.2020.1727808

[49] Izquierdo, M.S. (2001) Effect of Broodstock Nutrition on Reproductive Performance of Fish. Aquaculture, 197, 25-42. https://doi.org/10.1016/S0044-8486(01)00581-6

[50] Effiong, M.U., Akpan, W. and Ayotunde, E. (2014) Effect of Feeding Different Die- 
tary Protein Levels on Reproductive Biology of African Mud Catfish (Clarias gariepinus). Journal of Aquatic Resources, 29. https://www.ajol.info/index.php/jas/index

[51] Barua, P. (2011) Proximate Composition of Egg, Stomach Content and Body Composition of Pacu (Piaractus brachypomus) Collected from Aquatic Environment of Bangladesh. Current Biotica, 5, 330-343. http://www.currentbiotica.com

[52] Ekanem, A.P., Eyo, V.O., Udoh, J.O. and Udo, N.E. (2013) Effects of Unical Feed on Fecundity and Gonad Development of Clarias gariepinus, a Comparative Study with Coppens Commercial Feed in Earthen Pond. International Journal of Science and Research, 2, 8-14.

[53] Eyo, J.E. and Mgbenka, B. (1992) Aspects of the Biology of Clarias gariepinus in Anambra River Basin. 1. Oocyte Diameter, Fecundity and Sex Ratio. Journal of Agricultural Science and Technology, 2, 47-51.

\section{Abbreviations}

DM (Dry matter), CP (Crude Protein), CF (Crude fibre), ME (Metabolizable energy), UNBS (Uganda National Bureau of Standards), FAO (Food and Agriculture organization), HUFA (Highly unsaturated fatty acids) 